\title{
Influence of the Risk-Contributing Factors on the Financing of the Investment Project for Building of Intelligent Buildings
}

\author{
Nikolay Voytolovskiy ${ }^{1, *}$ Anatoliy Trebukhin ${ }^{2}$ and Vitaly Shoshinov ${ }^{2}$ \\ ${ }^{1}$ Sankt-Petersburg State Economic University, 21, Sadovaya street, St. Petersburg, 191023, Russia \\ ${ }^{2}$ Moscow State University of Civil Engineering, 26, Yaroslavskoye shosse, Moscow, 129337, Russia
}

\begin{abstract}
This article provides the generic classification of risks of the investment projects for the construction of intelligent buildings which differ by the detachment of the subjective perception of risk by the investor. Risk and uncertainty were justified as system characteristics of the investment projects for the construction of intelligent buildings. Characteristics of the development was given in the context of project management. Methodical schemes of the development of the investment project risks were specified on the basis of interconnection of risk and project effectiveness. Risk management procedure at realization of the developer project was developed.
\end{abstract}

\section{Introduction}

Development of any investment project starts with the formation of an investment plan, which may come from the needs of the country, particular region or to be initiated by a group of investors. Idea of the project can rise spontaneously in the process of work with experts in various fields of knowledge, or to be a result of the market research. Reasons of uncertainty inherent in the very nature of development as creation of the brand new unit, that inevitably means he destruction of the well-established relationships, changes in the internal and external communications of the object. Nature of these changes and results of the project can't be calculated with absolute accuracy because of huge array of the factors, which influence on the very environment and the newly created object and the impossibility of possession by absolutely all the information that is necessary for making definite decision. Developer makes the decisions based on the restriction information available to them, and, therefore, always has to deal with uncertainty.

\section{Methods}

Approach to the nature of risks as to uncertainty, which can be defined and calculated determines the basic stages of the risk management and research. In the most general form,

*Corresponding author: voytolovskiy@mail.ru 
algorithm of risk management in the processes of the management by development project can be represented as consisting of three main phases [1]:

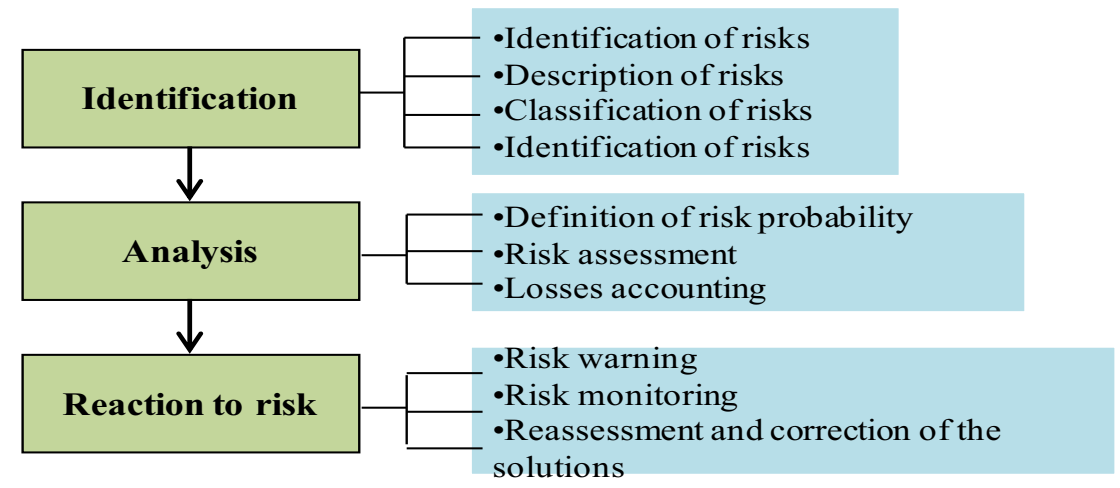

Fig 1. Risk management algorithm

Development projects have a number of features which make the issue of risk particularly important:

a) Complexity of assessment of the market reaction.

Any development project is not just an investment, but also an innovative process during which some new, unique on the characteristic of the product goes to the market, and therefore, it's extremely difficult to predict the reaction of the market on its appearance.

b) Multiplicity of the development participants.

Development projects is a complex techno-economic system, where a number of participants, the quality of which essentially depends on the final result of the project are involved. Each of these members is a potential carrier of the certain kind of risks, so developer shall forecast the risks associated with one or another participant of the market in the process of organization of interrelation of the participants, and to minimize their consequences.

c) Usage of attracted and borrowed money.

As has been mentioned above, main source of financing of development projects are the attracted by the developer funds of investors that imposes a special responsibility for the project risk minimization for the last one [2].

Stage 1. Identification of the development risks.

The basis for risk management is primarily qualitative analysis of risks, their detection and identification. Different approaches to the analysis of the risks and their classification, main types of which are presented of the fig. 2 are present in literature and on practice at studying of the investment problem at the real estate market. All risks arising from the realization of development projects can be divided into systematic and non-systematic risks [3].

Risk arising from the development process of all participants are systematic. Its lawful to highlight here such risks, which associated with all development projects and which can't be excluded on the separate level of the project management: risk of changes of the economic situation during the period of the project realization, risk of the low liquidity of the real estate as asset, risk of changes of the interest rates on the capital market and so forth.

In contrast to the systematic risks are unsystematic risks, which are "tied" to a particular project and its characteristics: location, type of project, quality of the project participants and so on. The main difference is that the non-systematic risks can be avoided, if not completely, then to be reduced to an acceptable level at the expense of the risk management, or at the expense of the efficient management of the project. 
Division into systematic and unsystematic risks, certainly cannot be considered as absolute one. For example, real estate risks (residential property, commercial real estate) can be partly attributed to the systematic (inherent to the all projects in the sphere of property), but partly they may also be regarded as non-systematic (because they can be controlled by the diversification of the activity of the companies, that, as mentioned above, is widely used in companies and developer's companies in Russia). Besides, it's important to intend that the division on the systematic and non-systematic risks is differ among different participants of the development process. For example, risks associated with the peculiarities of the real estate market are systematic for the developer, investor may consider them as non-systematic, because he has significantly wider selection box for the investment activity [4].

In general case thesis about different approaches to risk sharing can be formulated as: the more specific asset owned by the participant of the development process, the more systematic risks they have.

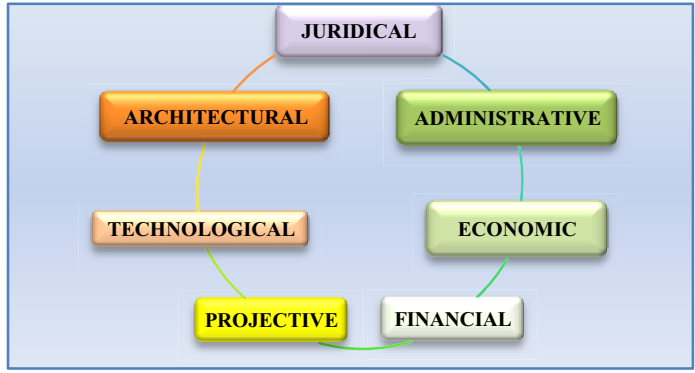

Fig 2. Grouping of risks and their factors

The given reasoning have the practical value in practice:

Firstly, separation on systematic and non-systematic risks allows to correctly determine the direction of the reaction of the developer on the identified risk: if it's about systematic risk, then it has to be considered at the developing of the project concept and is put in economic calculations at the determination of the financial expediency and economic efficiency of the project; if risk is in non-systematic category, then risk management measures must be provided.

Secondly, developer has to understand which risks are systematic or non-systematic for them for forecasting it at the creation of the mutual obligations system at the project realization.

It's important for developer to divide systematic and non-systematic risks depending on factors that cause them in addition to highlighting them. Let's analyze the factors, which determine the influence on the investment opportunities of the development (fig. 3) [5].

Lack of settlement of investment relations among key participants of development projects is the first of such factors. Another factor that significantly reduces opportunities of investment is the lack of information of legitimate information sources and databases characterizing the projects expected for realization, the available real estate units, lands and other elements of the investment process. To solve this problem is possible through the market researches with following localization of investment risks at the realization of development projects. In addition, there are problems of "adequate" taxation and excessive complexity of obtaining permits securities for their realization [6].

Then presented basic groups of economic risks which are divided into:

1. Risks, which determined by not deep enough analysis of tendencies and characteristics of the regional economy and real estate market:

- absence of analysis of state and prospects of the regional economy development; 
- Insufficiently representative analysis of the situation on the market of similar projects;

- Misinterpretation of the available data;

- Biased relation to the data;

- unfounded transfer of past experience on the future periods.

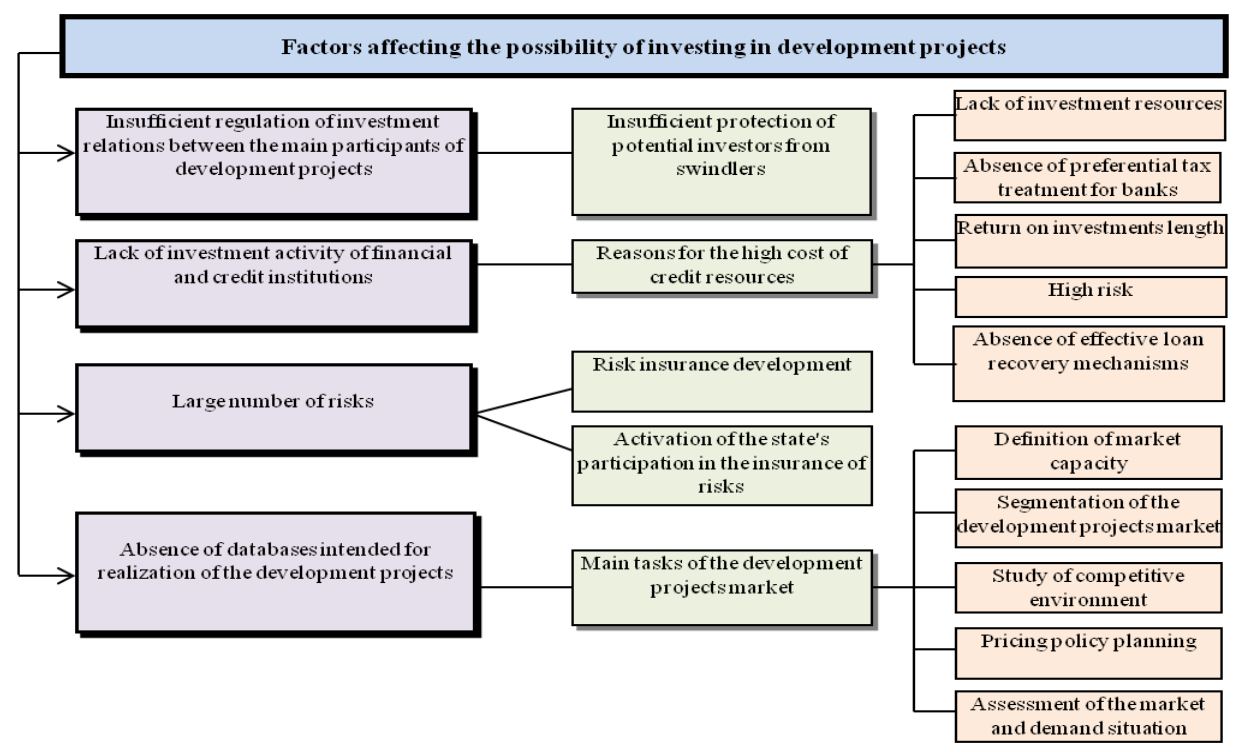

Fig. 3. External factors which has an influence on investment opportunities of development projects

2. Risks, which determined by incorrect organizational-economic decisions in such matters:

- Incorrect choice of legal form for realization of the project;

- Inefficient scheme of the resources attraction and mechanism of their return;

- Incorrect choice of the project participants.

Risks connected with volatility of the financial situation of investors in modern Russian conditions and the likelihood of risks from the part of the selected contractors has particular importance on the projects organization [6].

Eventually all types of risks have their financial measurement or increasing the costs of the project or transaction, or resulting in exceeding of their planned terms.

Stage 2. Analysis of the development risks

At the stage of the risk analysis in general case there can be highlighted two components of quantitative analysis of the risk of investment project [7]:

- sensitivity of its net present value to the changes of values of key the key performance indicators;

- amount of range of possible changes in key indicators, which is determined by its probability distributions.

\section{Results}

Developer is in the center of peculiar web, links individual members according to their function in the process of project realization. At the same time, as it can be already seen from the table 1, only part of members participates on each of stage of the development process, and only developer is a link, which gives a wholeness to the development process $[8]$. 
Table 1. Main participants of the development and their functions

\begin{tabular}{|l|c|c|c|c|c|c|c|c|c|}
\hline \multirow{2}{*}{ Stages of project } & \multicolumn{7}{c|}{ Participants of the development } \\
\cline { 2 - 12 } & O & D & S & I & CL & C & O & B \\
\hline Project initiation & + & $*$ & + & & & & & \\
\hline Assessment of the initiative & & $*$ & & & & & & \\
\hline Project results disposal & $*$ & $*$ & + & + & & + & + & \\
\hline Feasibility study and design & & $*$ & & & + & + & & \\
\hline Project Coordination with the government & & $*$ & $*$ & & & + & & \\
\hline Creation of the system of contractual relations & & $*$ & + & $*$ & $*$ & & & \\
\hline Implementation of the project (building) & + & $*$ & & & $*$ & & & \\
\hline $\begin{array}{l}\text { Ensuring of the legal possibility of sale of the } \\
\text { project and development of financing options }\end{array}$ & + & $*$ & & $*$ & & & & $*$ \\
\hline
\end{tabular}

Where: $\mathrm{C}$ is the owner of the real estate unit, $\mathrm{D}$ is the developer; PA is Public authorities; I is investors (individuals and legal entities); CL is contract labors (including subcontractors, designers); $\mathrm{C}$ is consultants; $\mathrm{O}$ is opponents; $\mathrm{B}$ is buyers; *-can perform in all cases, + - can perform/participate.

Besides the risks inherent to each of participants, a particular set of risks also corresponds to each of development stages, so the task becomes even more complicated. General assignment of the risk management is divided into a number of local problems, linked to the concrete stage and participant.

Table 2. Risk management at the stages of the development [9]

\begin{tabular}{|l|l|l|l|l|}
\hline $\begin{array}{l}\text { Stage of the } \\
\text { development }\end{array}$ & Identified risk & Participant & Consequences & Reaction to risk \\
\hline $\begin{array}{l}\text { Initiation of the } \\
\text { project }\end{array}$ & $\begin{array}{l}\text { Inadequate } \\
\text { assessment of } \\
\text { dynamics and } \\
\text { structure of the } \\
\text { market demand }\end{array}$ & Developer & $\begin{array}{l}\text { Absence of } \\
\text { demand for project } \\
\text { on the market }\end{array}$ & $\begin{array}{l}\text { Active marketing } \\
\text { researches }\end{array}$ \\
\hline $\begin{array}{l}\text { Assessment of } \\
\text { the initiative }\end{array}$ & $\begin{array}{l}\text { Revaluation of the } \\
\text { financial } \\
\text { attractiveness of } \\
\text { the project }\end{array}$ & $\begin{array}{l}\text { Developer } \\
\text { Owner }\end{array}$ & $\begin{array}{l}\text { Absence of the } \\
\text { funding sources } \\
\text { of the project }\end{array}$ & $\begin{array}{l}\text { Revision of the project } \\
\text { concept }\end{array}$ \\
\hline $\begin{array}{l}\text { Ensuring of the } \\
\text { legal } \\
\text { possibility of } \\
\text { sale of the } \\
\text { project and } \\
\text { development } \\
\text { of financing } \\
\text { options }\end{array}$ & $\begin{array}{l}\text { Insufficient study } \\
\text { of issue of the } \\
\text { rights on the land } \\
\text { plot } \\
\text { Backlash of the } \\
\text { opponents } \\
\text { for the project }\end{array}$ & $\begin{array}{l}\text { Developer } \\
\text { Opponents }\end{array}$ & $\begin{array}{l}\text { Non-registrability } \\
\text { of the created } \\
\text { object and rights } \\
\text { on it } \\
\text { Inability to start the } \\
\text { project }\end{array}$ & $\begin{array}{l}\text { Detailed legal analysis } \\
\text { and preparation of the } \\
\text { project. Holding of } \\
\text { public hearings. }\end{array}$ \\
\hline $\begin{array}{l}\text { Feasibility } \\
\text { Organization of the } \\
\text { positive response for } \\
\text { the project from public }\end{array}$ \\
\hline design
\end{tabular}




\begin{tabular}{|l|l|l|l|l|}
\hline $\begin{array}{l}\text { Creation of the } \\
\text { system of } \\
\text { contractual } \\
\text { relations }\end{array}$ & $\begin{array}{l}\text { Bank's refusal in } \\
\text { credit } \\
\text { accommodation }\end{array}$ & $\begin{array}{l}\text { Investor } \\
\text { Bank }\end{array}$ & $\begin{array}{l}\text { Failure to meet the } \\
\text { project realization } \\
\text { delivery date }\end{array}$ & $\begin{array}{l}\text { Change in the } \\
\text { financing scheme } \\
\text { Clarification of the } \\
\text { economic indicators of } \\
\text { the project }\end{array}$ \\
\hline $\begin{array}{l}\text { Implementa- } \\
\text { tion } \\
\text { of the project }\end{array}$ & $\begin{array}{l}\text { Disruption of } \\
\text { construction } \\
\text { deadlines by the } \\
\text { contractors }\end{array}$ & Contractor & $\begin{array}{l}\text { Slowdown } \\
\text { of the realization of } \\
\text { the project, } \\
\text { possibility of } \\
\text { defaulting on loan } \\
\text { to the Bank }\end{array}$ & $\begin{array}{l}\text { Tendering of contracts } \\
\text { realization. Inclusion to } \\
\text { the contract positions } \\
\text { about the size of } \\
\text { contractor's } \\
\text { responsibility in case of } \\
\text { violation of the contract }\end{array}$ \\
\hline $\begin{array}{l}\text { Project results } \\
\text { disposal }\end{array}$ & $\begin{array}{l}\text { Excess of the } \\
\text { timing of the object }\end{array}$ & $\begin{array}{l}\text { Realtor- } \\
\text { consultant }\end{array}$ & $\begin{array}{l}\text { Increase in terms } \\
\text { of return on } \\
\text { investment }\end{array}$ & $\begin{array}{l}\text { Earlier start of sales. } \\
\text { Revision of the } \\
\text { marketing policy }\end{array}$ \\
\hline
\end{tabular}

\section{Discussions}

In general, the content of some of these problems is presented in Table 2. The following table recites not all risks faced by the developer in the realization of the project and as can be seen from the examples of risks stated above, with overwhelming majority they bounded with activity not of the developer, but of his partners and opponents. At the same time developer bears the ultimate accountability before the investors, consumers, public authorities for the project realization. Realization of the key points of development projects depends on the risks arising in connection with the participation of government institutions, different contracting institutions, etc.

\section{Conclusion}

Project realization often affects the interests of the higher-level structures in relation to the direct participants of the project. These structures may be involved in the realization of the project or affect its realization even not being parties. Calculation is performed according to the sum of cash flows from the investment, operating and financial activity. Receipt and payment of loans only from the external environment are accounted in this structure.

All the basic techniques are based on the criteria of the net present value, internal rate of return and cash flow discounting methods at the assessment of the public and commercial effectiveness of projects of the construction of the intelligent building project. Different methods of estimation of efficiency of the project offer different approach to the definition of the risk-contributing factors on the financing and accounting of the risks.

\section{References}

1. P.G. Grabovy, A.K. Orlov. Procedia Engineering, 153, 195-202 (2016)

2. V.S. Kankhva, Immovable property: economy, management. 3-4, 17-19 (2009)

3. S.A. Baronin, Real estate economy management, 1, 58-62, (2009)

4. R. Brazauskas, J. Le-Rademacher. Computer Methods and Programs in Biomedicine, 135, 199-207 (2016)

5. I. Kardes, A. Ozturk, S.T. Cavusgil, E. Cavusgil, International Business Review. 22, 905-917 (2013)

6. M. Olaru, M. Şandru, I. Carmen Pirnea, Procedia - Social and Behavioral Sciences, 109, 940-943 (2014) 
7. S.V. Domnina, E.V. Savoskina, N.V. Shekhova. Procedia Engineering, 153, 741-746 (2016)

8. E.U. Dorokhina. Methodology for the risk management of project-oriented companies (Academia MNEPU, St. Petersburg, 2011)

9. E.K. Chirkunova, E.E. Kireeva, A.D. Kornilova, J.S. Pschenichnikova, Procedia Engineering, 153, 112-117 (2016) 